\title{
The Informalization of Belonging: Igbo Informal Enterprise and National Cohesion from Below
}

\author{
Kate Meagher*
}

\begin{abstract}
The Nigerian Civil War evokes images of ethno-regional strife followed by simmering ethnic tension. However, political perspectives on the legacies of Biafra tend to gloss over the more integrative and constructive economic effects of the Civil War and its aftermath. While the Nigerian Civil War devastated Igbo business activities across Nigeria, and precipitated a mass return of Igbo migrants to their home area, it also laid the foundation for a consolidation and rapid development of Igbo informal enterprise, which has had integrative rather than divisive social and economic consequences for Nigeria as a whole. Operating below the radar of political competition, the demands of informal enterprise development have nurtured strong inter-ethnic and inter-regional links between the Igbo, Hausa, Yoruba and other Nigerian as well as non-Nigerian groups. With a particular focus on Igbo informal manufacturing, long-distance trading networks and informal money changing, this paper will consider the role of the informal economy in the development of popular structures of national unity. It will also show that these processes of economic integration from below have increasingly been strained by political struggles from above, creating a tide of violence and ethnic polarization that, even more than the Civil War, threatens to unravel the underlying social fabric of Nigerian nationhood.
\end{abstract}

\section{Résumé}

La guerre civile nigériane évoque des images de conflits ethno-régionaux suivis d'une tension ethnique latente. Toutefois, les perspectives politiques sur l'héritage du Biafra ont tendance à se dissimuler dans les effets économiques plus intégratifs et constructifs de la guerre civile et ses séquelles. Si la guerre civile nigériane a anéanti les activités économiques igbo à travers le Nigéria et a

* Development Studies Institute, London School of Economics and Political Science. E-mail: k.meagher@lse.ac.uk. 
précipité un retour massif des migrants Igbo vers leur région d'origine, elle a également jeté les bases d'une consolidation et d'un développement rapide de l'entreprise informelle Igbo, ce qui a eu des conséquences économiques et sociales intégratives pour le Nigeria dans son ensemble, plutôt que d'être une source de discorde. Opérant sous le joug de la concurrence politique, les exigences du développement des entreprises informelles ont nourri de solides relations interethniques et interrégionales entre les Igbo, les Hausa, les Yoruba et d'autres Nigérians ainsi que des groupes non-nigérians. Avec un accent particulier sur les industries manufacturières informelles Igbo, les réseaux interurbains de commerce informel et de change Le présent article examine le rôle de l'économie informelle dans le développement de structures populaires de l'unité nationale. Il montre également que les processus d'intégration économique ont été de plus en plus compromis par les luttes politiques susmentionnées, ce qui a ainsi créé une vague de violence et de polarisation ethnique qui, plus encore que la guerre civile, menace de défaire le tissu social qui sous-tend la nation nigériane.

\section{Introduction: Marginalization or Informal Integration?}

The Nigerian Civil War is often seen as an event that crystallized ethnic divisions in Nigeria, and led the Igbo people down a trajectory of marginalization from political and economic power. While there is no doubt that, since the Civil War, the Igbo have faced systematic exclusion from the most influential positions in the state and the formal economy, Igbo traders, artisans and business people have achieved legendary success in the informal economy. Land shortage, strong indigenous commercial institutions and a relentless competitive ethos have spurred high levels of out-migration and the development of wide-ranging informal trading networks, not to mention one of the most dynamic informal manufacturing sectors in Africa (Northrup 1978; Brautigam 1997). Far from representing an ethnically insular and exclusive strategy, Igbo advancement within the informal economy has involved the development of strong inter-ethnic linkages and cooperative relations with other Nigerian ethnic groups. While ongoing conflicts over an equitable share of the national cake continue to threaten national cohesion from above, Igbo engagement in the informal economy has been knitting the country together from below.

The conventional view is that Igbo involvement in the informal economy has been a divisive rather than a uniting force. High levels of migration and Igbo dominance of lucrative trades in other ethnic regions of Nigeria, particularly in the Hausa areas of the north, have been represented as important triggers of ethnic riots, both in the run-up to the Civil War, and during serious outbreaks of violence during the 1990s. Just prior to the Civil War, Wayne Nafzinger (1968) argued that ethnic networks were highly exclusive, 
highlighting ‘barriers to inter-tribal (sic) economic relations’ such as language and credit. He maintained that in Nigerian informal business systems, people could only trust those from a similar socio-ethnic background, and suggested that the Civil War was likely to further undermine the prospects for economic cooperation between ethnic groups.

A closer look at popular economic organization, however, reveals a very different picture. Some scholars have noted that migratory pressures and a dependence on informal economic relations with other groups have encouraged the development of strong integrative tendencies among the Igbo. As Harniet-Sievers (2006:126) observed in his comprehensive study of Igbo ethnic identity: 'The long history of Igbo migration and ethnic identity formation before 1966 always included productive interaction with other groups. It continued after 1970 in the everyday life of the re-established Igbo diaspora.' While Igbo economic success at the popular level, as well as their monopolization of profitable activities such as the trade in auto parts, has been a source of resentment and sometimes of conflict, particularly in northern Nigeria, Douglas Anthony points out that such ethnic divisions were mitigated by widespread integrative strategies of Igbo living in northern Nigeria. Whatever cultural and economic divisions arose, Anthony (2002:33) reminds us that 'any generalized depiction of the gulf between groups fails to take into account the ability of individuals to build bridges. ... friendships, marriage, commercial and political cooperation, and simple civility played a key role in connecting individuals and, sometimes, communities'.

As Tom Forrest argues, this ability to 'build bridges' with other ethnic communities was not peculiar to the Igbo of the diaspora. It also played a vital role in the rapid development of local industrialization within the Igbo states following the Civil War. Indeed, studies by Forrest (1994) and Brautigam (1997), as well as my own research (Meagher 2006), demonstrate that local industrial dynamism in south-eastern Nigeria did not represent a withdrawal into parochial forms of economic organization, but involved the development of complex trading and productive linkages with other Nigerian ethnic groups, as well as with traders from other parts of Africa and from as far away as East Asia, all without the assistance of the state. The legendary success of Igbo trading and manufacturing networks since the Civil War has been a product of cooperative relations across ethnic cleavages rather than of ethnic exclusivity. As one Igbo informant observed, 'historically we migrated and saw that it was good to have foreigners’ (Forrest 1994:169). While communal solidarity has played a central role in Igbo economic advancement, symbiotic forms of institutionalized collaboration with other ethnic groups have been just as critical for widening markets and gaining access to new sources of labour, technology and skills. 
In this paper, I will examine the ways in which Igbo involvement in the informal economy, which has been intensified by their post-war marginalization from political and economic power, has strengthened Nigerian inter-ethnic cohesion from below, even as political struggles weaken it from above. This is not to argue that popular frameworks of economic and social solidarity are sufficient to counter divisive forms of political mobilization for this is clearly not the case - but simply to highlight some of the ways in which Igbo relations with other ethnic groups serve to weave Nigeria together amid the high-profile struggles that threaten to tear it apart. I will begin with a brief examination of the ways in which Igbo identity formation and economic circumstances have encouraged the development of institutions of cooperation across ethnic boundaries. Focusing on Igbo informal activity since the Civil War, I will proceed to show how integrative economic linkages have fostered Igbo economic dynamism both in the diaspora and at home, while simultaneously promoting cohesive relations with other ethnic groups. Examples will be drawn from economic relations between Igbo and Hausa groups in rural as well as urban northern Nigeria, and also from inter-ethnic relations underpinning the much-celebrated development of informal manufacturing in the Igbo home states of south-eastern Nigeria. While these are not tales of unremitting optimism, they highlight some of the ways in which popular, and often ethnic, forms of organization provide social resources for national integration amid the polarizing forces unleashed by ethnic competition over oil rents.

\section{Igbo Identity and the Nigerian Social Fabric}

The process of Igbo identity formation has involved integrative economic and religious linkages across communal, and often ethnic, boundaries. As a stateless society plagued even in pre-colonial times by severe land shortage, the socio-economic organization of Igbo communities has been characterized by high levels of mobility and institutions of inter-communal cooperation, fostering dynamic regional trading systems. With the coming of colonialism, the consolidation of a unitary Igbo identity was accompanied by a widening Igbo diaspora, creating commercial contacts with a greater range of Nigerian ethnic groups. Even during the Nigerian Civil War, what appeared to be a withdrawal into a more insular form of commercial and ethnic organization laid the foundation for new forms of informal economic cooperation with Nigerian as well as non-Nigerian ethnic groups. Throughout their history, cooperation across communal and ethnic cleavages has played a central role in Igbo economic survival and identity formation.

Although stateless and dispersed in pre-colonial times, Igbo communities 'were embedded in a variety of networks establishing translocal, regional, 
and even more far-reaching connections without any overarching governing institutions' (Harniet-Sievers 2006:43). These connections, referred to by Silverstein (1983) as 'pan-Igbo' institutions, bound Igbo society together in a broad cultural and economic sphere despite the absence of a common ethnic identity. In the centuries before colonialism, cross-cutting institutions such as oracular religions, title societies and hometown-based occupational specialization linked Igbo communities together through trade, ritual and juridical practices. Secret societies, as well as the use of blood pacts (igbandu), ritualized friendship bonds and strategic marriages, contributed to expanding relations of trust, trade and commercial infrastructure outside the bounds of kinship and community (Isichei 1976:65; Northrup 1978:967; Dike and Ekejiuba 1990:290). Membership in elite societies such as ojo or okonko conferred what Oriji described as a 'Pan-Igbo passport' for safe passage through the fragmented territory of sometimes warring Igbo communities. Participation in such societies provided ritualized protection from attack, as well as supplying a ready infrastructure of resting houses and binding obligations for assistance across community lines (Onwuejeogwu 1981:67; Oriji 1982:533). Indeed, Northrup (1978:109) even cites a case of a European trader who joined a south-eastern Nigerian secret society in order to benefit from their effective debt collection machinery.

In the centuries before colonialism, this framework of trust and protection across community lines supported the development of a remarkable market infrastructure, including roads, currencies, credit systems and networks of local and regional markets. Credit networks, based on the 'trust system', operated across clan and even ethnic boundaries, linking Igbo communities with the trading peoples of the coast (Dike and Ekejiuba 1990:243-5). Through this institutional matrix of social relations, religious sanctions and economic infrastructure, the decentralized polities of pre-colonial Igboland were bound together by 'a dense network of tiny capillary veins' (Isichei 1976:67). These historical processes contributed to the development of indigenous economic networks that were not hampered by the limitations of primordial identities. On the contrary, what is most striking about the Igbo is their remarkable capacity for institutional innovation across kinship and community lines. Religious, associative and inter-community relations as well as ties of kinship and community coalesced into economic networks that contributed to the widening of social identities. The fact that neither the Igbo, nor the powerful Aro sub-group, constituted primordial ethnic identities testifies to this reality. The Aro emerged from a fusion of three ethnic groups, involving the Akpa, the Igbo and the Ibibio, melded into a single identity group through institutionalized political and economic organization (Dike and Ekejiuba 1990). 
Clearly struck by the integrative social tendencies of commercial organization within the region, Northrup (1978:230) argues that:

In southeastern Nigeria the long process of commercial development ... occurred with little regard for large state structures or for national or ethnographic frontiers. ... It was economics not ethnicity, trade not rulers which governed the main lines of this region's pre-colonial past.

The colonial era encouraged the consolidation of this socio-economic matrix into a unitary ethnic identity, while at the same time widening the sphere of Igbo economic operation. While the Igbo have historically had a significant presence among the coastal peoples of south-eastern Nigeria, their expansion into western and northern Nigeria took place largely in the context of colonialism. Propelled by economic and population pressures, the Igbo rapidly took advantage of new economic opportunities available across Nigeria, moving to locations across the country. Igbo groups migrated widely within the Igbo areas, but the bulk of migration was outside the Igbo hinterland to western and northern Nigeria, as well as to neighbouring countries such as Ghana, Cameroun and Fernando Po, giving rise to a new grouping known as 'the Igbo diaspora' (Onwubu 1975:404).

The Igbo diaspora created a network of Igbo inhabitants in nearly every corner of Nigeria. The 291 Igbos enumerated in Lagos in 1911 had risen to 31,887 by 1953 . By the 1950s, there were 167,000 Igbos in northern Nigeria, making them the southern ethnic group with the highest population in the northern region (Anthony 2000:423; Isichei 1976:209). By the 1950s, there were substantial Igbo minorities in non-Igbo cities as far flung as Ibadan, Zaria, Lafia, Maiduguri, Gusau, Kafanchan and Makurdi. The 1953 census recorded that 15 per cent of the Igbo population lived outside Igboland, making the Igbo the largest migrant population in Nigeria, both in proportionate and absolute terms. As Anthony points out, the five most important Igbo political figures of the 1950s and 1960s were all either born or raised in northern Nigeria.

Silverstein (1983:130) argues that the rapid expansion of the Igbo diaspora was a product, not only of population pressure at home, but of the prior development of social 'blueprints for migration' in pre-colonial Igbo social organization. The organization of craftsmen and traders into itinerant groups with specialized territories created a framework for migration that did not rupture linkages between migrants and their home areas. Institutions requiring the annual return of migrants to their hometown for festivals had already begun to emerge in pre-colonial times (Dike and Ekejiuba 1990:216ff). As Silverstein (1983:355) shows in her study of Nnewi entrepreneurs, systems of apprenticeship also followed a diasporic pattern, in which masters settled 
apprentices in other parts of Nigeria so as to widen their networks and avoid problems of oversupply in a given area.

These developments took advantage of opportunities provided by new colonial arrangements, but depended essentially on indigenous organizational efforts. While Igbo informal enterprise was tolerated by the colonial government, it was given little encouragement, and no real support. After Nigerian Independence in 1960, Igbo informal traders and producers became even more marginalized in the face of state efforts to promote the development of the formal economy. The Kilby Report on small-scale industry in Eastern Nigeria, based on fieldwork conducted in 1961, identified an active smallscale manufacturing sector that had essentially been left to 'shift for itself' (Kilby 1963:6). The Nigerian Civil War, from 1967 to 1970, intensified the role of self-reliance in the development of Igbo enterprise. Brautigam (1997:1006) and Forrest (1994:195-6) suggest that the Civil War encouraged a trend toward accelerated local industrialization in the context of the threeyear siege of the Igbo State of 'Biafra', and the subsequent marginalization of the Igbo after their defeat. Even after the war, local self-help institutions, and a capacity for economic and social accommodation with other ethnic groups, played a central role in the recovery of Igbo enterprise, at home and in the diaspora.

Despite the traumatic experience of violent expulsion and defeat in a long civil war, high levels of Igbo out-migration were resumed soon after the end of hostilities, owing to the ongoing pressures of land scarcity, limited employment opportunities at home, and intense competition for economic advancement (Anthony 2002:228). While the government policy of 'no victor, no vanquished' facilitated relations of ethnic accommodation for returning Igbo migrants, the lack of state assistance in the process of reconstruction, combined with disadvantageous policies governing the economic reintegration of Biafra, crippled Igbo participation within the formal economy, intensifying their focus on informal systems of economic organization.

\section{New Economic Frontiers: Igbo Informal Enterprise in Northern Nigeria}

Faced with a devastated homeland and a lack of reconstruction assistance from the state, the Igbo turned to rebuilding their livelihoods through migration almost as soon as the war was over. This included a rapid return to northern Nigeria, where the violence against Igbos had been most severe. As Harniet-Sievers (2006:124) observed, 'The Igbo returned to Nigeria with surprising speed, the Igbo diaspora beginning to re-establish itself in Western and even in Northern Nigeria within a few months after the end of the 
war.' For some years, investment strategies within the diaspora appeared more insular, as returnees and new migrants attempted to re-establish themselves economically and restrategize in the wake of the traumatic experience of their expulsion from the north. After their return, Anthony (2002:218) notes that Kano's Igbos 'chose to invest their personal wealth at home in Igboland rather than in their adopted cities'. However, Anthony also notes that, by the 1980s, after contributing to reconstruction in their home communities and securing fall-back housing at home, Igbo migrants began to build in Kano again. Moreover, the gradual re-establishment of Igbo hometown and ethnic associations in Kano, far from representing a shift toward ethnic insularity, regularly included non-Igbo members from southern minority groups who lacked sufficient numbers to form effective associations on their own.

In addition to living and investing in property in Hausa areas, Igbo traders were also engaging in increasingly structured commercial relationships with Hausa traders. While the trade in car parts has remained an essentially Igbo business, the trade in used clothing, pioneered in West Africa by the Igbo, expanded through cooperation between Igbo and Hausa trading networks. As Forrest (1994:181) explains, Igbo second-hand clothing importers based in Cotonou and Lomé extended the trade northward into Sahelian countries through contacts with Hausa traders. In a relationship of cooperation rather than competition, the vast Hausa trading systems of Sahelian West Africa became integrated into the second-hand clothing business as distributive networks for Igbo importers and traders. While the Igbo traders lacked the networks and commercial infrastructure to compete with the Hausa in the Sahel, the Hausa have, until recently, lacked the overseas networks to enter effectively into the import of used clothing. Conversely, Hausa dominance of the informal currency exchange business across most of Nigeria has been accompanied by cooperative relations with Igbo currency traders, who have maintained a monopoly on the business in Igbo areas (Hashim and Meagher 1999). Igbo traders regulate structural imbalances in the supply and demand for CFA francs in south-eastern Nigeria by routinely recycling currency through the Hausa-controlled informal currency market in Kano. Hausa and Igbo currency traders alike treat this as a form of structural collaboration, despite the interface of two ethnic monopolies in the same business.

As economic pressures built up in the wake of structural adjustment and the political machinations of an epileptic return to civilian rule, renewed conflicts between Igbo migrants and their Hausa hosts in northern Nigerian towns have been accompanied by symbiotic Igbo penetration into northern villages. Politically manipulated riots in the northern Nigerian cities of Kano 
and Kaduna in 1991, 1995 and 2000, based on religion rather than ethnicity, resulted in the slaughter of thousands of Igbo migrants, and have encouraged some to abandon hopes of living peacefully in the north. But an equally common response to mounting economic and political competition in northern cities has been a migration of young Igbo entrepreneurs into large villages in search of new economic opportunities opened up by the economic realignments of structural adjustment. Strong communal training and credit networks, and a familiarity with life in the north, have equipped young Igbo entrepreneurs to seize new opportunities in large northern villages.

In the late 1990s, I conducted research on non-farm activities in a village of 12,000 inhabitants in Kaduna State, and found that three Igbo entrepreneurs had recently set up business there (Meagher 2001). Two had come to revive an abandoned bakery after the ban on imported wheat was lifted in 1992, making local bread production appear profitable again. One had come to open a branch of his brother's pharmacy, since the setting up of a private clinic in the wake of the 1996 meningitis epidemic had increased the demand for a local supply of medicine. These young men came to join another Igbo family who had been running a general provisions shop in the village for decades without incident. All of the Igbo residents found relations in the village congenial, and one of the recent arrivals, whose shop was the favourite hangout for village youth, had already been offered some land and was being encouraged by villagers to marry a local girl. Although both of these new Igbo ventures closed after only a few years, the reason in both cases was linked to the weakness of local markets in the wake of structural adjustment rather than to any problems in local ethnic relations.

In these various cases, social and commercial relations between Igbo and Hausa communities suggest a continued ability to 'build bridges' at the popular level. Ethnic specialization and integrative social processes have by and large created frameworks of social integration, which contrast sharply with the ongoing outbreaks of violence against Igbos in the north. On the one hand, the intensifying economic pressures of structural adjustment have begun to weaken some of the more integrative dimensions of Igbo-Hausa relations; on the other, political agendas of ethnic manipulation in elite struggles over oil resources continue to play a central role in outbreaks of violence. Despite recurring episodes of horrific slaughter of Igbos in the north, however, Douglas Anthony’s (2002:33) reflections on the Civil War continue to ring true:

The forced departure of Igbos from Northern Nigeria in 1966 was first and foremost a product of political and economic competition between elites. ... left to their own devices, ordinary Nigerians would not - could not - have accomplished the horrors that they did under the influence of some of their leaders. 


\section{Informal Industialization in Igbo States}

While the growth of an economically dynamic Igbo diaspora has continued unabated, the Civil War has also had the effect of stimulating a rapid growth of trade and local industry within the Igbo areas of Nigeria. At the epicentre of the Igbo manufacturing industry, the towns of Aba and Nnewi have been referred to as the 'Japan of Africa', while the term 'Aba made' has become a popular Nigerian expression for cheap local manufactures. There has been a tendency to link Igbo industrial dynamism to the economic incentives created by structural adjustment, but a number of scholars have shown that the conditions for local industrial development were laid over a decade earlier in the context of the Civil War. Tom Forrest (1994:196) points out that the war precipitated a sudden shift toward the repatriation of capital to Igbo areas for investment at home. The rapid injection of private capital from the diaspora, backed by a 'self-help' ethos of reconstruction, led to a boom in local industrialization within the Igbo states. Forrest (1994:148) emphasizes that:

The rural industrialization of Anambra and Imo states owes little to government policies in any direct sense. It is the product of strong community ties, the loss of properties outside Igboland ... and the need for security in the aftermath of the northern massacres and the civil war.

In its initial stages, the development of Igbo local industry looked like a withdrawal into ethnic exclusiveness. At home, most Igbo artisans, traders and businessmen had to make a new start after the war, owing to widespread destruction of assets, loss of property and the collapse of the Biafran currency (Forrest 1994:193). Igbo in the diaspora, especially traders operating in Cotonou and Lomé who had escaped the worst effects of the war, sent money home for investment in houses, trade and manufacturing. In Nnewi, the experience of the war gave rise to a collective decision that Nnewi businessmen should locate some of their activities at home, partly in response to the thousands of refugees from the North, and partly to take advantage of economic changes that arose during the war (Forrest 1994:161). Credit and capital from the Igbo diaspora was also critical to the setting up of local manufacturing in Aba. The support of Abiriba and Onitsha traders was particularly central to the development of the shoe and garment sectors in Aba, at the formal and the informal levels (Forrest 1994:171-5; Meagher 2006).

But the rise of Igbo manufacturing went hand in hand with a need for wider markets and new sources of labour. Following the takeoff of Igbo manufacturing in the early years of structural adjustment, the burgeoning cluster of shoe firms in Aba began to take on non-Igbo labour from nearby southern minority groups, largely through local apprenticeship institutions. 
One shoe producer even claimed to have had a Yoruba apprentice. By the mid-1990s, a sizeable number of southern minorities headed firms within the shoe cluster, with their own specialized products. In interviews, non-Igbo shoe producers maintained that they experienced no disadvantages from being non-Igbo, and had been able to build up effective credit, supply and distribution networks with Igbo traders (Meagher 2004). In the informal garment industry of Aba, a taste for northern Nigerian and Sahelian fashions during the late 1990s precipitated a demand for Hausa embroiderers, who are far more skilled at embroidery than the Igbo. A sizeable Hausa quarter in the town of Aba hosted skilled embroiderers, who were hired on piece rates by local Igbo tailoring firms. Again, symbiotic relations prevailed, since the Aba tailors and workers lacked the skills for fine embroidery, and the Hausa embroiderers lacked the capital and local business knowledge to set up tailoring shops in the southeast. Similarly, Brautigam (1997) and Forrest (1994) highlight the central role of Igbo linkages with Taiwanese businessmen, who provided the machinery and the training for the setting up of local car parts production in Nnewi.

In both Aba and Nnewi, far-flung informal trading and transport networks played a crucial role in the widening of markets that underpinned the expansion of local manufacturing. Initially, Igbo traders with networks extending into West and Central Africa distributed locally produced goods to neighbouring countries, but already by the 1980s, Yoruba and Hausa traders were coming directly to Igbo towns to purchase goods for themselves. By the mid-1990s, traders from as far as Cote d'Ivoire, Ghana and Zaire frequented the Aba shoe and garment clusters to purchase large consignments of goods. In the shoe cluster, francophone traders, known locally as 'Ca va', were prized customers owing to their tendency to purchase large orders, and a knowledge of French was considered an asset in the Aba shoe cluster.

Contrary to Nafzinger's (1968) claim that there is little scope for interaction between ethnic economic systems in Nigeria, Igbo shoe and garment producers regularly participated in credit relations with Yoruba and Hausa traders. Some Igbo shoe producers specialized in the type of cheap children's shoes popular among Hausa traders, creating a dependence on Hausa customers, and a constant interplay of credit relations. Indeed, one Igbo shoe producer claimed that he preferred granting credit to Hausa rather than Igbo traders. He explained that his Hausa customers were more likely to repay credit, while fellow Igbo customers tended to expect understanding for the many reasons why they could not (Meagher 2004). Interestingly, national origins had more of an influence than ethnicity on credit decisions. While the majority of Aba informal producers were happy to grant credit to customers outside their own ethnic group, a significant proportion in both 
clusters were less willing to grant credit to non-Nigerians, who visited the cluster less frequently, and were too difficult to trace in the event of default.

By the late 1990s, the livelihoods of Igbo small-scale manufacturers were inextricably intertwined with the activities of non-Igbo traders and labour. As a result, a serious escalation of organized crime in the area precipitated the rise of a local vigilante group, the now notorious Bakassi Boys, to make the town safe for visiting traders (Human Rights Watch/CLEEN 2002). Alarming rates of robbery and murder, combined with an inefficient and corrupt police force, constituted a particular threat to local manufacturers and business people as they were beginning to frighten away out-of-town traders who had become the mainstay of demand for local goods. In fact, 98 per cent of informal shoe producers, and nearly 40 per cent of garment producers were dependent for the bulk of their sales on traders taking goods to other parts of Nigeria and beyond. It is not a coincidence that the incident said to have triggered the spontaneous formation of the Bakassi Boys vigilante group was the murder of a Calabar woman trader on her way to buy shoes in Aba. While the Bakassi Boys went on to become a violent tool of preelectoral thuggery, they originated from the need for Igbo informal producers to make the town safe for non-Igbo traders coming in from other parts of Nigeria. Moreover, the transformation of the Bakassi Boys into a murderous militia involved the wresting of control over the vigilante group from the informal shoe producers who formed it. Over time, authority over the vigilante group was seized by top officials of the Igbo state governments, especially Anambra and Abia States, who sought to use the Bakassi Boys in the service of their own political agendas in the run-up to the 2003 and later the 2007 elections (Meagher 2007; Ukiwo 2002).

Once again, elite competition, rather than popular antagonisms, proved to be at the centre of the ethnic violence associated with the Bakassi Boys. In the process of their political takeover by Igbo state governors, the Bakassi Boys became involved in an ethnic riot in Aba - one of the first incidents in Nigeria in which the Igbos were the aggressors and the Hausas the victims. In February 2000, in retaliation against the killing of Igbos in the northern city of Kaduna in anti-Shari'a riots, the Bakassi Boys led an attack on the Hausa communities of Aba and other nearby towns. Over 300 northerners were killed, and many more had their property destroyed and were forced to flee to the police station for safety. Two things were particularly striking about this incident. The first was that the massacre of Hausa migrants was against the economic interests of the informal producers who founded the Bakassi Boys, and still made up a significant proportion of its membership. People from the north of Nigeria were frightened away from the town for 
months, and many shoe and garment producers dependent on Hausa custom and Hausa skilled labour claimed that business did not return to normal for up to a year afterwards, undermining the livelihoods of local manufacturers. Indeed, the Aba riots dramatically exposed the widespread economic interdependence between the Igbo areas and the north. Not only were the livelihoods of local producers and traders hard hit by the riots, but local consumers across the town faced scarcity and threefold increases in the price of key foodstuffs, such as meat, tomatoes and onions, which are brought in by informal herders and traders from northern Nigeria. Created to make the town safe for strangers, the Bakassi Boys ended up chasing away the very people they were meant to protect, a fact noted and lamented by many Igbo residents at the time.

Perhaps even more perplexing was the extremely rapid return of the Hausa residents of Aba. Less than two weeks after the riots, Hausa migrants could be found chatting beside the wrecked mosque, the black smudges left by the burned bodies of their fallen brothers still visible on the road barely fifty yards away. I passed through the Hausa quarters every day during this period, and this remains for me one of the most chilling images of Nigerian identity politics. Part of the explanation for the rapid return of the Hausa community lies in the fact that many Hausa migrants had lived in the area for years, in some cases generations. Whatever the ethnic differences, Aba was their home, the location of their property and centre of their economic and social networks. Also important is the fact that the attack against them was led by only a small segment of society, made up largely of frustrated and underemployed youth whipped up by political propaganda - something the migrants themselves recognized. The vast majority of Aba's Igbo residents not only abstained from the violence, but protected Hausa friends and workers by hiding them from attackers, and came in a steady stream to the police station and Hausa quarters afterward to apologize, commiserate and bring food and clothing.

The repercussions of the Aba riots were addressed at a commercial as well as a communal level. A couple of weeks after the riots, the Kano shoe traders' union sent a delegation to the Aba shoe producers saying that they were not going to allow traders from Aba to do business in Kano until Aba was safe for Kano traders to return to. The Kano delegation, made up of Igbo as well as Hausa traders, claimed it was unfair for them to be prevented from trading in Aba because of insecurity while Aba people continued to trade in their markets in Kano. The leaders of the Aba shoe producers, who at that time still had some influence over the activities of the Bakassi Boys, gave assurances that Kano traders could return to Aba safely. After that, Hausa traders gradually began to resume trade with the Aba shoe cluster, 
which at that time still housed the central office of the Bakassi Boys vigilante group. Although it took some time for trade with the north to return to normal, informal economic institutions provided effective channels for Hausa and Igbo informal business people to negotiate mutually acceptable solutions.

\section{Conclusion: Formal Divisions, Informal Integration}

Since the Nigerian Civil War, a politics of marginalization, grievance and ethnic competition has led to mounting concerns about the sustainability of Nigeria as a nation. Below the surface of these political struggles, however, increased Igbo participation in the informal economy has fostered more cohesive social and economic relations with other Nigerian ethnic groups. The objective of highlighting this paradox is not to give the impression that $\mathrm{Ni}$ geria's problems of social cohesion would be better handled by popular forms of governance, without interference from the state. This is manifestly not the case. As Douglas Anthony makes clear, in the aftermath of the Civil War the state policy of 'no victor no vanquished' played an important role in facilitating the reintegration of the Igbo into Nigerian society, supporting ideologically if not materially the self-help efforts of Igbo migrants. The objective here is rather to point out that the competitive ethnic mobilization currently practised at the political level is only one dimension of ethnic relations in Nigeria. Below the strategies of identity politics lie more integrative forms of organization embedded in popular social and economic practices, some dating back centuries, other emerging in response to new political and economic circumstances.

Recent literature on the 'uncivil' character of Nigerian society, and of African societies more generally, suggests that strong ethnic identities prevent Africans from forming collaborative links across ethnic cleavages (Fatton 1995; Ikelegbe 2001; Reno 2002). This interpretation is challenged by the realities of Igbo informal economic organization. Indeed, this account of informal economic relations between the Igbo and other Nigerian ethnic groups suggests that popular forms of social and economic organization contribute to the resilience of a multi-ethnic Nigerian society in the face of increasingly violent forms of identity politics. In the face of pessimistic assessments of the capacity of African societies to govern themselves, there is a need to draw attention to the existence of institutionalized forms of ethnic accommodation and conflict resolution operating under the surface of the state. Commentators on the informal economy have repeatedly argued that the institutional legacies of the informal economy provide important resources for meeting new organizational challenges. Informal forms of organization, as Grabher and Stark (1997:3) remind us, 'are not simple residues from the past but can serve as resources for the future'. 
While offering cause for optimism, however, a realistic analysis of the role of the Igbo in contemporary national cohesion must also sound a note of warning. Even the underlying social fabric of informal ethnic collaboration can be torn apart by the mounting ethnic violence instigated by the political manoeuvres of Nigerian elites, including Igbo elites. Integrative forms of popular economic and social organization provide a measure of resilience in the face of divisive identity politics, but they cannot withstand current levels of conflict and violence indefinitely. Warning signs are already visible. Departing from previous patterns, the Igbo now launch counter-attacks in response to Hausa violence against them, and despite the rapid return of migrant communities after incidents of violence, a growing number of migrants are fleeing at the first sign of trouble, and some are returning home for good. All of these are indications that the tenacious fabric of Nigerian society is beginning to unravel in the face of increasingly savage political struggles among elites. If this continues, there will eventually be nothing to hold the pieces together. Just as institutions of inter-ethnic collaboration can become embedded in popular economic and social practices, ethnic antagonism and conflict can also become socially embedded. A state that fails to nurture informal forms of inter-ethnic cooperation will eventually destroy them.

\section{References}

Anthony, D., 2002, Poison and Medicine: Ethnicity, Power and Violence in a Nigerian City, 1966-1986, Oxford: James Currey.

Brautigam, D., 1997, 'Substituting for the State: Institutions and Industrial Development in Eastern Nigeria', World Development 25(7): 1063-80.

Dike, K. O. and Ekejiuba, F. I., 1990, The Aro of South-eastern Nigeria, 1650 1980: A Study of Socio-economic Formation and Transformation in Nigeria, Ibadan: Ibadan University Press.

Fatton, R., 1995, 'Africa in the Age of Democratization: The Civic Limitations of Civil Society', African Studies Review 38(2): 67-100.

Forrest, T., 1994, The Advance of African Capital: The Growth of Nigerian Private Enterprise, [Edinburgh]: Edinburgh University Press for the International African Institute.

Grabher, G. and Stark, D., 1997, ‘Organizing Diversity: Evolutionary Theory, Network Analysis, and Post-socialism', in G. Grabher and D. Stark, eds., Restructuring Networks in Post-Socialism: Legacies, Linkages, and Localities, Oxford: Oxford University Press

Harniet-Sievers, A., 2006, Constructions of Belonging: Igbo Communities and the Nigerian State in the Twentieth Century, Rochester: University of Rochester Press. 
Hashim, Y. and Meagher, K., 1999, Cross-border Trade and the Parallel Currency Market: Trade and Finance in the Context of Structural Adjustment: A Case Study from Kano, Nigeria, Uppsala: Nordiska Afrikainstitutet.

Human Rights Watch/CLEEN, 2002, The Bakassi Boys: The Legitimation of Murder and Torture, Human Rights Watch Reports, 14(5), A 1-45.

Ikelegbe, A., 2001, 'The Perverse Manifestations of Civil Society: Evidence from Nigeria', The Journal of Modern African Studies 39(1): 1-24.

Isichei, E. A., 1976, A History of the Igbo People, London: Macmillan.

Kilby, P., 1963, The Development of Small Industries in Eastern Nigeria, Lagos: Ministry of Commerce; USAID.

Meagher, K., 2001, The Bargain Sector: Economic Restructuring and the Nonfarm Sector in the Nigerian Savanna, Aldershot: Ashgate.

Meagher, K., 2004, 'Identity Economics: Informal Manufacturing and Social Networks in South-eastern Nigeria', unpublished D.Phil. thesis, University of Oxford.

Meagher, K., 2006, 'Social Capital, Social Liabilities, and Political Capital: Social Networks and Informal Manufacturing in Nigeria', African Affairs 105(421): 553-82.

Nafzinger, E. W., 1968, 'Inter-Regional Economic Relations in the Nigerian Footwear Industry', The Journal of Modern African Studies 6(4): 531-42.

Northrup, D., 1978, Trade Without Rulers: Pre-Colonial Economic Development in South-Eastern Nigeria, Oxford: Clarendon Press.

Onwubu, C., 1975, 'Ethnic Identity, Political Integration, and National Development: The Igbo Diaspora in Nigeria', The Journal of Modern African Studies 13(3): 399-413.

Onwuejeogwu, M. A., 1981, An Igbo Civilization: Nri Kindom and Hegemony, London; Benin City: Ethnographica; Ethiope.

Oriji, J. N., 1982, 'A Re-assessment of the Organisation and Benefits of the Slave and Palm Produce Trade amongst the Ngwa-Igbo', Canadian Journal of African Studies 16(3): 523-48.

Reno, W., 2002, 'The Politics of Insurgency in Collapsing States', Development and Change 33(5): 837-58.

Silverstein, S., 1983, Sociocultural Organization and Locational Strategies of Transportation Entrepreneurs: An Ethnoeconomic History of the Nnewi Igbo of Nigeria, Boston University. 